\title{
BUILDING COALITIONS: Extra Resources for Coalitions
}

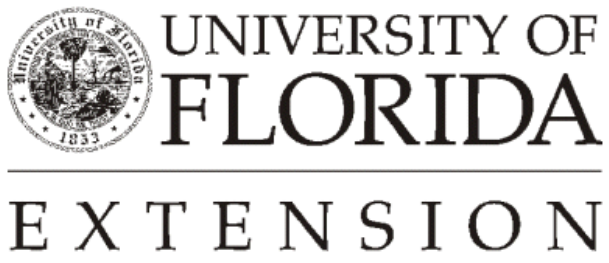

Institute of $\mathbf{F}_{\text {ood and }} \mathbf{A}_{\text {gricultural }} \mathbf{S}_{\text {ciences }}$ 


\section{Notes on Fundraising and Grant-Writing}

Organizations join coalitions or collaborations to combine various resources in working toward a shared goal. What if additional resources are needed?

Usually coalitions seem to prefer less formal in-kind-type resource sharing. One organization might provide meeting space, another agrees to provide copying and postage. Sometimes, a more formal memorandum for sharing larger resources may be used. For example, one organization may agree to provide a specified amount of a staff member's time to work on a particular coalition effort. In other situations, the coalition may decide that member agencies do not have the needed resources available. Then, it may be necessary to undertake some sort of fundraising.

The search for funds may take one of two basic directions, a general fundraising campaign, or the submission of a specified proposal to a foundation or public organization.

You need to find out which funding sources are out there, who can tap them, what the rules are for using them and how to secure them. A funding search should embrace both private and public sources.

\section{Fundraising}

There is no magic in fundraising. Above all, you need to be a good planner, organizer, manager and marketer. When these skills are combined with enthusiasm and common sense, you will be successful.

Fundraising requires pre-planning and a well-organized execution. Generally, it is not something that can be done well in response to a crisis. Designate someone as the chief fundraiser. Give that person the authority and responsibility to represent the cause and to raise the money needed. Provide the clerical and other kinds of support he or she needs to get started and do not expect instant results.

Building a group's credibility in the community takes time and that is the basis for a successful development program. People must be aware of you and have a positive impression of what you do and how you manage your resources before they will support you.

\section{Six Steps to Raising Money}

\section{Set program goals.}

- Develop objectives to reach your goals.

- Plan the methods you will use to reach those objectives.

- Design specific activities to carry out the methods. 


\section{Inventory all your resources.}

- $\quad$ Preview all the people and organizations in your community who might be able to help.

- Brainstorm with key staff and volunteers. Develop a specific list of names, individuals, civic organizations, political organizations, media, business, etc.

\section{Develop a fundraising campaign.}

- A well-structured annual campaign includes the use of as many fundraising techniques as are necessary to move toward that ultimate goal.

- $\quad$ Bill Riley, Kansas 4-H Foundation Director considers a good fundraising campaign like a baseball diamond. It has four major parts:

- $\quad$ Vision--Goals, purpose, potential prospects.

- Cultivation--Informs prospects of goals and current activities before the request for funds is made (brochures, media, contacts).

- $\quad$ Solicitation--The actual request to potential donors for general or specific purpose and how they will be contacted.

- $\quad$ Recognition--How you thank donors and inform the public when appropriate.

To hit a "home run" with your efforts, all four parts should be developed before a campaign begins. Any costs associated with fundraising should be included in the campaign budget (including brochures, postage, plaques or mementos), with the funds to be raised for program activities. The Ohio State University Winter 1990 BUCK\$ LINE contains helpful information on the "successful ask" that relates to cultivation and solicitation. It underlines how there should be an ongoing, two-way relationship with potential donors, not just a "quick hit-and-run to the bank."

\section{Assess your financial and personnel needs.}

- $\quad$ Decide what you need in people, money, services and products to reach the fundraising goals.

\section{Implement fundraising activities.}

- New programs are best funded by one or two large gifts from foundations or corporations. 
- $\quad$ Programs that do not have new components are more easily funded through a variety of annual campaign activities, such as a membership drive and special events.

- $\quad$ Development activities must be planned to support the programs.

- $\quad$ Consider recruiting civic groups to do benefits: car washes, bake sales, a dance, a spaghetti dinner or fish fry. Not only do they raise money, but you have a great chance to educate them about the issues you are working to solve--with their support.

\section{Evaluate your results.}

- $\quad$ Assess what went well and what went badly in every project as each is completed:

- Did you reach the goals?

- How much money did you raise before expenses?

\section{Foundation Grants, Government Grants and Contracts:}

When you are unable to secure all the needed funds from within your own community, foundation grants and government grants and contracts can help. Many foundations are interested in helping reputable community groups in meeting local needs. Competition for funding can be stiff.

Generally, all funding organizations like to see an organized plan or proposal for upcoming activities and expenditures. It is not uncommon for a foundation to initially ask for a brief letter (two to three pages) telling about the organization, your plans and the amount of funding requested. These requests should describe the following in specific terms:

- $\quad$ The nature of the problem to be addressed.

- $\quad$ The solution proposed.

- $\quad$ Documentation of the group's ability to carry out the objectives.

- $\quad$ Financial needs associated with the request, including evidence that the effort will not rely solely on the funder's support.

- Documentation that a systematic evaluation will be carried out to demonstrate that funding has made a difference. 
The process of preparing proposals for government funding depends on the funding agency. Although different programs may require different formats for the proposals, applicants for government funding should be prepared to include the following standard sections in their proposals.

- $\quad$ Proposal Summary--The summary appears at the beginning of the proposal. It should interest the reader in what is to follow. When applications are screened, the summary may be the only part of the proposal read.

- Institutional Background and Qualifications--The discussion of the organization should be clear and to the point. Leave a favorable impression without overloading the reader with unnecessary details.

- $\quad$ Statement of the Problem--This is the most important part of the proposal. It tells the reader why you want to perform the activity for which you require funding.

- $\quad$ Program Objectives--Program objectives need to be stated in measurable terms. Statements about objectives should be quantifiable: use terms like "to increase" or "to reduce" instead of ones like "to create" or "to provide."

- Methods or Technical Approach--The next step is to explain the methods by which you propose to achieve your objectives. This section should present a reasonable scope of activities that can be accomplished within the time allotted for the program and the applicant's resources.

- Evaluation--It is important to carefully plan the evaluation of your activities at the inception of the project and not as an afterthought. Many evaluations depend on measuring certain characteristics before the program activities begin. Funding agencies expect you to have given thought to evaluating the proposed program during proposal preparation.

- $\quad$ Future and Other Necessary Funding--When requesting funding for a new project, financial planning should go beyond the proposed grant period. Show funders you are planning. The funding arena is a competitive one, and it is not without its own politics. Few sources will fund any project beyond three years. They prefer to "rotate" resources since needs are always greater than dollars available in any year. They also want to avoid any long-term personnel costs, usually in the fringe benefit area.

If the problem is long-term, a coalition is likely to have two alternatives. The problem or need should be limited so the approach is do-able within the period the funds are available. If long-range staff needs are foreseen, the coalition needs to approach the regular source of dollars about assuming continuing costs for the position(s). The availability of a funding source might be limited. Some organizations fund "new, innovative" efforts for short periods, then move on to other "innovative" approaches to community priorities. This provides the donor with regular visibility to the public. 
- $\quad$ The Budget--Varying degrees of detail are required in an estimated budget. Funding organizations usually provide budget forms and instructions for their completion. Be specific when preparing your budget. Funding sources do not like to see every cost estimate rounded upward and expect to be presented the true anticipated costs (to the best of your ability).

\section{Obtaining Funds for Problem Solving Projects}

After members of a community organization begin to address a problem, they frequently consider developing a special program or project. Remember time is a resource that coalition members already possess. Before rushing into writing a proposal, figure out whether this is what you really want. Despite whether you are applying to a foundation, corporation or a government agency, there will always be many more requests than there are funds available.

The benefits of obtaining a grant, compared with how time could otherwise be spent, may not make it worthwhile to seek the funds. Is the projected program realistically within the capability of the agency? Government funders, for example, might request that projects reduce delinquency by an unusually large percentage. Contracting with unrealistic expectations guarantees failure. The period for funding may not be conducive to the accomplishment of agency objectives.

The lure of funds has its price in conditions and restrictions. There may be limitations on client eligibility, constraints on the manner in which clients will be served, qualifications required of staff, prescribed methods of reporting agency activities, review of internal agency records, fiscal accounting review and the restraints on being able to criticize governmental bodies. There is always the potential for conflict between the funder's need for control and the organization's requirement for autonomy. What are the possible consequences of the program being ended after a designated period? What are the potential effects on staff and, more importantly, on clients if the project cannot continue to receive funds? An assessment must be made of the prospects for continuing the program, or the consequences of its discontinuance, before the proposal is submitted.

Cash flow is another problem related to reimbursement. Anticipate a time delay between the submission of the first invoice and the receipt of funds.

The clear message: know what you are getting into when you consider applying for funds.

\section{Identifying Funding Sources}

Hundreds of foundations exist in any large or even moderate-sized urban community. Find which ones are right for your coalition. The best approach is to identify initially a core of foundations that match your interest.

To learn about community, private and corporate foundations, write to the Foundation Center, 888 Seventh Avenue, New York, NY 10106. They provide a catalogue that describes major sources of 
information about foundations. The Center also has a cooperating network of 90 library reference collections in all 50 states Mexico and Puerto Rico. Contact the Center, (212) 620-4230, in New York to find out the location of the branch in your state.

The federal government prints sources of information that can alert you to available program grants. One of the most significant of these is the Federal Register, published each weekday. The "Highlight" section in the front lists major topics. The "Notices" section describes grant availability. Announcements are made of rules governing programs, so that, though money is not immediately available, you gain some idea of what grants are likely to be funded later. It is available at most major or public university libraries, or can be obtained by writing to Superintendent of Documents, U.S. Government Printing Office, Washington, D.C. 20402 for subscription information.

\section{Identifying In-Kind Services}

For almost any cost, investigate the possibility of in-kind contributions. These often cover the entire cost of a service, staff person, etc., but they also can be used creatively with other funding. There are several types of in-kind services:

- $\quad$ Space, including maintenance and utilities

- $\quad$ Staffing

- $\quad$ Clerical assistance

- $\quad$ Equipment and furniture

- $\quad$ Construction and renovation

- $\quad$ Printing facilities

- Transportation

- $\quad$ Public relations and promotional activities

- $\quad$ Recreational activities

Sometimes this type of resource is also called a "non-cash" contribution. Sometimes with foundation or government grants, "in-kind" services need to be documented carefully for audits, while the requirements for "non-cash" contributions are less rigid. 


\section{Non-Funded Proposals}

What if your proposal is not funded? In true problem-solving style, consider the options: resubmit a revised proposal, abandon the project or pursue other avenues that might solve the problem, though with fewer resources. If, on the other hand, you have the good fortune to be funded, you know that ahead possibly lie frustrations, crises, accountability for results and worries about refunding.

\section{About Incorporating}

Should your coalition or corporation incorporate or file as a tax-exempt organization? Often, many or all the member organizations of a group already have this status. Is it necessary to apply as a coalition? There are three basic considerations. The first is the time, effort and some cost in going through the process of incorporation, and possibly some ongoing cost for fiscal reporting. The coalition needs to designate someone to act on its behalf in this matter. If the group is seeking a startup grant, an agency can be designated to do this and the grant can cover the costs. The advantage of incorporation is that a clear identity is established. The disadvantage is the need to stick to much more formal operating rules and procedures.

The second point to consider is that in many coalitions, several "lead organizations" emerge who have the strongest interest in furthering the group's goals. Usually, there may be the possibility of working out collaborative programs with one or more agencies. These groups could be designated to receive funds and administer them for a program carried out to further the aims of the coalition. This can avoid many complexities of establishing a separate framework.

Finally, the legal structure of incorporation makes it necessary to have a formal "funeral" if for some reason the coalition expires or disbands. This involves additional effort, sometimes some costs, and can create some negative publicity for member organizations if the media interprets disbanding as a sign of failure in solving a problem or situation.

\section{Thoughts on Funding for Coalitions}

The funding source can have a profound influence on the structure of a coalition. If the coalition is formed in response to a funding initiative, much of its direction has been established. To qualify for certain grant and foundation funds, it may be necessary for the coalition to meet special conditions of membership, board structure and staffing.

Funding is available from many sources, both public and private. Multiple sources may be preferred to avoid total obligation or association with a single source. But it often means more administrative work and complying with a variety of rules and regulations. Multiple funding can stabilize an operation and ensure its survival, but securing this mix requires staff time and a well-developed coalition structure. Securing multiple funding usually requires a grant person on the staff, an established identity, documentation of organization history and data, credibility and leverage. Multiple funding to alleviate undue influence by a single funding source is most important for self-regulating and advocacy coalitions. It is least vital for information and resource sharing and for technical assistance coalitions.

Levels of funding influence structure because they rarely are sufficient to accomplish the desired objectives. Although there is often considerable donated time and resources, these cannot always make up for lack of physical facilities and sufficient staff. Despite their purpose, all coalitions can be more effective if they have a constant funding level and do not have to constantly search for program funds. 


\section{References}

Brody, Ralph. Problem Solving Concepts and Methods/or Community Organizations. Cleveland: Human Sciences Press, Inc., 1982.

Croan, Gerald M. and Joan F. Lees. Building Effective Coalitions: Some Planning Considerations. (Prepared for The Office of Juvenile Justice and Delinquency Prevention), 1979.

Lifer, Charles and Carla Menelle. BUCK\$L1NE, Winter, 1990, Columbus: Ohio Cooperative Extension Service, The Ohio State University, 1990.

Melaville, Atelia and Martin J. Blank. What It Takes: Structuring Interagency Partnerships To Connect Children and Families with Comprehensive Services. Washington, DC: Education and Human Services Consortium, 1991.

Menelle, Carla. "Preparing Proposals." Money Lines, Columbus: Ohio Cooperative Extension Service, The Ohio State University, 1990.

. "The Many Sources of Funding." Money Lines. Columbus: Ohio Cooperative Extension Service, The Ohio State University, Ohio, 1990.

Riley, William. "Orientation to Fund Development." Presentation at National Association of Extension 4-H Agents' Conference, Greenbrier, West Virginia, 1990.

Robinson, Estelle R. and Aleta You Mastney. Linking Schools and Community Services, A Practical Guide. Center for Community Education School of Social Work, Rutgers University, 1989.

\section{Authors}

Penne Smith, County Extension Agent, 4-H, CNRD, Chair, Ohio Cooperative Extension Service, The Ohio State University.

Gregory P. Siek, Assistant Professor, County Extension Agent, 4-H, Ohio Cooperative Extension Service, Ohio State University.

(C)1992 The Ohio State University

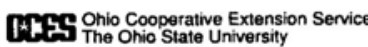


This series on Coalition Building was developed by The Ohio Center For Action on Coalition Development for Family and High Risk Youth, Richard Clark, Ph.D., Director. It has been adapted for County Extension Faculty in Florida to facilitate work with local and regional organizations and groups such as non-profits, cooperatives, county extension associations, and others that might benefit from a plan for working together to achieve support for mutual goals.

This document is FY500, Part 8 of the 16 part series adapted for use in Florida by Elizabeth B. Bolton, Professor, Community Development and Lisa Guion, Assistant Professor, Program Planning and Evaluation; Department of Family, Youth and Community Sciences, Florida Cooperative Extension Service, Institute of Food and Agricultural Sciences, University of Florida, Gainesville, 32611-0310.

Reprinted with permission March, 1997. Revised April, 2002.

The Institute of Food and Agricultural Sciences is an equal opportunity/affirmative action employer authorized to provide research, educational information and other services only to individuals and institutions that function without regard to race, color, sex, age, handicap, or national origin. For information on obtaining other extension publications, contact your county Cooperative Extension Service office.

Florida Cooperative Extension Service/Institute of Food and Agricultural Sciences/University of Florida/Christine Taylor Waddill, Dean 